\title{
Interpretations of Fyodor Dostoevsky's “The Idiot” by Akira Kurosawa and Andrzej Wajda: A comparative analysis
}

\author{
X. Wang \\ Lomonosov Moscow State University \\ 1, Leninskie gory, Moscow, 119234, Russian Federation
}

For citation: Wang X. Interpretations of Fyodor Dostoevsky's "The Idiot" by Akira Kurosawa and Andrzej Wajda: A comparative analysis. Vestnik of Saint Petersburg University. Asian and African Studies, 2018, vol. 10, issue 2, pp. 159-175. https://doi.org/10.21638/11701/spbu13.2018.202

\begin{abstract}
Literary heritage of Fyodor Dostoevsky has always presented an attraction for world cinema encouraging and inspiring filmmakers from different countries including Asia to rethink and reinterpret the works of this outstanding Russian writer again and again. A remarkable effort toward "re-coding" of Dostoevsky's narrative was made by Asian cinematography, namely by Akira Kurosawa, a Japanese film director and screenwriter. "The Idiot" directed by Kurosawa holds a special place among other adaptations of Dostoyevsky's masterpiece primarily on account of this film exhibiting free and bold changes as regards the place and time of action. In Kurosawa's interpretation events unfold in post-war Japan of the mid- $20^{\text {th }}$ century around Japanese characters brought together on a snowy island of Hokkaido. Placing the story in a Japanese frame and content Kurosawa makes the film not a mere illustration of Dostoevsky's novel, but succeeds in accurately transmitting the spirit of the masterpiece. This significant Japanese film director and screenwriter reveals a deep understanding of the Russian world while remaining an informed transmitter or bearer of Asian culture. The way Kurosawa approaches Dostoevsky's novel constitutes his subjective rethinking of this literary work observed through the lense of his homeland's history and national tradition. Ancient Asian culture is clearly seen both in the storyline and visual imaging of the film. Like in his other films, in «The Idiot» Kurosawa introduces the Noh drama. This paper attempts to analyze Akira Kurosawa and Andrzej Wajda's cinematic narratives, to identify characteristics of their artistic styles, and to reveal some specific features of adapting Russian classics in an Eastern cultural context.
\end{abstract}

Keywords: Fyodor Dostoevsky, The Idiot, Akira Kurosawa, Nastasja, Andrzej Wajda, Noh Drama, Kabuki.

The idea to transfer the masterpiece "The Idiot" by Dostoevsky to the medium of "moving photography" was brewing within cinematographic circles from the very inception of the art of cinema. For instance, the eponymous film by P. Chardynin premiered in the film studio of A. Khanzhonkov in 1910. Literary heritage of Dostoevsky has been a point of attraction for many Russian filmmakers (I. Pyr'ev, V. Bortko, R. Kachanov) as well as for cinematographers from other countries and has until now lost none of its relevance - the fact that, if anything, only confirms the enduring human value of the novel authored by that outstanding Russian novelist.

When it comes to adjusting literary masterpieces to screen, filmmakers are primarily challenged with choosing between the two approaches - that of descriptive (or narrative)

(c) Санкт-Петербургский государственный университет, 2018 
screen adaptation and that of filmmaker's own interpretation. While the former is aimed mainly at conveying a writer's ideas to a wide audience, the latter is construed as a way for a filmmaker to focus on his or her own subjective experience and apprehension with respect to the original source, and it is there that conceptual, at times experimental artistic techniques are employed. A true mastery would be capable of achieving harmony between these two perspectives.

Screen adaptation of a literary piece is a major challenge when the filmmaker belongs outside the culture which the author of the work represents. Besides, adaptation requires not only transformation of a written into a visual text, but, more significantly, re-writing one cultural code in terms of another.

In this regard two films named "The Idiot" and "Nastasja”, one of which was directed by a Japanese film director and screenwriter Akira Kurosawa (1951) and the other - by a world-famous Polish cinematographist Andrzej Wajda (1994) seem to be especially interesting and promising research areas. Both film-makers seem to comprehend a similarity of fundamental principles in Dostoevskian and Japanese aesthetics. Through a comparative approach this study is aimed at analyzing the "film language" as well as at revealing key artistic techniques and concepts of the two film makers as regards their re-interpretation of "The Idiot" by Dostoevsky. This study is also focused on the specificity of reinterpretations which appears whenever a Russian literary classic is set in the context of an oriental culture.

One of the earlier significant non-Russian cinematic interpretations of Dostoevsky's novel was produced by a French director Georges Lampin who filmed "The Idiot" in 1946. The part played by young Gérard Philipe was one of the first and vibrant parts in his career. While using traditional film-making techniques, Georges Lampin offers his subjective reading of the heroes' characters and conflicts arising between them in accordance with his own contemporary world and cultural peculiarities of his homeland. Thus, he provides Prince Myshkin with more physical resemblance with Jesus Christ and leading edge thinking on social issues. In his speech before the Yepanchins Myshkin passionately declares his principles of commitment to social changes and reformation. As for the Yepanchins they are presented in film as proponents of conservative and cynical views. Rogozhin appears to be a discreet bourgeois and thus the conflict between Prince Myshkin and Rogozhin is deeply grounded in class contradictions.

The Japanese developed an interest to Dostoevsky's writing quite a long time ago. The first encounter of Japanese readership with the writer's masterpieces happened in 1892 when the Japanese translation of "Crime and Punishment" made by Uchida Roan from an English version of the novel was released. A Japanese translation of "The Idiot" appeared in 1914. The literary heritage of the great Russian novelist had a tremendous impact on Japanese literature of a new age. Inspired by Dostoevsky's poetics, Ftabatei Simei, a Japanese writer and translator of Russian literature, authored "Floating Cloud" — a significant novella for this era [1]. "After the defeat of Japanese militarism in 1945 in the ruins of the country, in the atmosphere of liberation and existential psychology Japanese intelligentsia were very excited about Dostoevsky writing» [1, p. 181]. This was the grounds for a new "school of Dostoevsky" in Japanese literature which was represented by a number of eminent writers. "The Dostoevsky creative writing became a kind of guidance for them, a mirror reflecting agony of consciousness". Modern literary thought of Japan still employs expression "Experience of Dostoevsky" [1, p. 186]. 
And it is during this time that Akira Kurosawa, who had a keen interest in Fyodor Dostoevsky's writings since his childhood, embarked on a screen adaptation of Dostoevsky's novel "The Idiot". By then his name had become widely known due to the film "Rashomon" (羅生門 Rashōmon). Concerning his decision to make an adaptation of "The Idiot" Kurosawa said the following:

«I had wanted to make this film long before "Rashomon" ... Since I was little I've liked Russian literature, and have read the greater part of it, but I find that I like Dostoevsky the best, and had long thought that this book would make a wonderful film. He is still my favorite author, and he is the one - I still think who writes most honestly about human existence» $[2, \mathrm{p} .81]$.

Deep humanity of the writer seemed to Kurosawa highly relevant to Japan of his day.

«He has this power of compassion. And then he refuses to turn his eyes away; he, too, looks; he, too, suffers. There is something which is more than human, better than human about him» $[2$, p. 81$]$.

Kurosawa did not treat the novel as a finished, fully shaped substance, whether we are talking about the narrative plan or the way of seeing the human soul, but rather he saw in it a conceptual framework that could be used to reflect on his own history and personal attitude.

The events of the novel are carried from Saint Petersburg of the 1860s to the snowy island of Hokkaido of the mid-20 $0^{\text {th }}$ century. Well-known characters of Dostoevsky's "The Idiot" - Prince Myshkin, Nastasya Filippovna and Parfyon Rogozhin - are replaced by Japanese characters with typical Japanese names, looks, style of dress and communication etiquette.

These changes in time and place are intended not merely to adapt the novel for Japanese audience but rather to express one's heartfelt response provoked by the encounter with the novel. In fact "The Idiot" was created in an atmosphere of increasing polarization within Russian society, of a breakaway from traditional values, it was the time when the souls of new generation according to Lizaveta Yepanchina were filled with "chaos, outrage". "Our age of crime and railways" - this is how the author identifies his modernity through the mouth of another character.

A similar situation was evident in Japan almost a century later. The country which had been closed to the outside world for centuries was going through a time when millennial traditions were being shattered during rapid industrialization and the actual transition from a feudal system to a capitalism, which involved economic and moral crises, whereby lots of suffering was being experienced from the loss of identity compounded by the military defeat and subsequent American occupation. At the end of the war the Japanese people were in a confused state terrified by an unknown future; at the same time many of them were filled with the joy of life at the thought that they had escaped an "Honorable Death of the Hundred Million".

The day of the Japanese capitulation was recalled by Kurosawa painfully and vividly in his memoir "Something Like an Autobiography":

"On August 15, 1945, I was summoned to the studio along with everyone else to listen to the momentous proclamation on the radio: the Emperor himself was to speak over the air waves. I will never forget the scenes I saw as I walked the streets that day. On the way from Sōshigaya to the studios in Kinuta the shopping street looked fully prepared 
for the Honorable Death of the Hundred Million. The atmosphere was tense, panicked. There were even shop owners who had taken their Japanese swords from their sheaths and sat staring at the bare blades.

However, when I walked the same route back to my home after listening to the imperial proclamation, the scene was entirely different. The people on the shopping street were bustling about with cheerful faces as if preparing for a festival next day» [3, p. 145].

Inspired by his experience of post-war Japan Kurosawa transforms Dostoevsky's hero Prince Myshkin into a Japanese man named Kinji Kameda who returns to Japan not from a Swiss sanatorium but from Okinawa where he has been treated in an American army hospital. Kurosawa's hero is a former prisoner of war of the American army who was accused of a crime and nearly executed. He escaped death by minutes when the Americans had got an exculpatory evidence. The hero, like the majority of Japanese people, was forced to pay for the sins of his country's past. Kameda lives directly - it was his personal experience - what Dostoevsky's Prince Myshkin knows about from the outside, what Dostoevsky experienced himself on the scaffold, and what people of Japan felt at the very end of the war. Believing that he has only few minutes before execution, unaware of his imminent reprieve, Kameda is consumed with immense love and compassion to all living creatures. Comparing to Dostoevsky's Prince Myshkin who managed to retain his childish worldview due to his congenital disease, it is the whole experience that has led Kameda to his illness. Kameda's infinite goodness and compassion appear a posteriori, resulting in his mental shock. The theme of suffering, as critics note, is an integral part of Kurasawa's conceptual framework being "the kind of redemptive model it offered the culture during this chaotic time" $[4$, p. 70$]$ :

"With defeat in World War II, many Japanese, who had made the objectives of the nation their objectives in life, were dumbfounded to find that the government had lied to them and was neither just nor dependable. During this uncertain time Akira Kurosawa, in a series of first-rate films, sustained the people by his consistent assertion that the meaning of life is not dictated by the nation but something each individual should discover for himself through suffering" [5, p. 116].

Kurosawa perceives excellent qualities of his hero as expressing the highest degree of catharsis which a Japanese person being in a state of post-war stress and trauma should be striving for.

Kurosawa's film is segmented into two parts, "Love and Suffering" and "Love and Hate." While setting the narrative in Japan Kurosawa focuses primarily on the main plot line reducing the other lines and secondary characters. At the heart of the story is Kameda (Prince Myshkin) with his refined susceptibility, pure, innocent and lofty soul in his naivety - and sometimes even saintliness, and the love quadrangle between Kameda, Taeko Nasu (Nastasya Filippovna), Denkichi Akama (Parfyon Rogozhin) and Ayako (Aglaya).

The film opens with Kameda's scream when he wakes up from a terrible dream about the exile. The opening scene introduces the hero as a third-class passenger of a ship arriving in Hokkaido. Kameda tells Akama about his memories of the keen perception of existence he experienced before exile. Akama looks at him leniently and patronizingly. The two of them meet for the first time. The scene of Kameda and Akama's meeting is intended to expose main features of their characters masterfully embodied by the two remarkable actors of their generation — namely Masayuki Mori and Toshiro Mifune. Ku- 
rosawa's choice of actors for this film was very accurate. Mifune with whom the director started collaborating as early as in 1948 was an inexhaustible source of unbridled life force and fitted the role of Rogozhin perfectly.

Masayuki Mori well known for his subtle, psychological acting, with his chiseled twitchy face which expressed quivering compassion sparkling in his eyes, turned out to be exactly the "good and beautiful person" in line with the Dostoevsky's concept. [6, p. 134]. Setsuko Hara, one of the most prominent actresses of the Japanese cinema, embodied the passionate and proud image of a Japanese Nastasya Filippovna.

In his study "The Films of Akira Kurosawa" Richie claims that

"Kurosawa's choice of Hokkaido as locale seems due to its long contact with Russia; it might be thought closer to Dostoevsky's milieu than any other area in Japan. In this northern island the traditional modes of Japanese living are not common. Chairs and tables are widely used, for example. At the same time the people have some of that peculiarly inward quality which one finds in snow-countries" [2, c. 81].

The climate on Hokkaido is, indeed, very similar to that of Russia. The very first scenes of the film, where Akama and Kameda arrive to Sapporo, picture a real winter season atmosphere: a heavy snowfall, wooden houses sunk in snow up to their roofs. There is a blizzard, too, and the Russian song called "Monotonously the little bell is sounding" is heard from the loudspeaker. That is why the audience may often feel ambiguous about the epoch and the country in which the story is set. "Feather-legged" horses harnessed together in a shaft bow with bells pulling a wooden sledge, snow banks, a boy in a dog-sled carrying firewood, pauper street vendors... and a juxtaposition with trams and nice cars.

However, it is difficult to agree with Richie's suggestion about Kurosawa' motivation in his choice of Hokkaido as locale. External resemblance between Hokkaido and Russia seems to be something merely superficial. Deeper insight reveals that Kurosawa framed the narrative within a specific time and place setting. Thus, in the second part of Dostoevsky's novel events unfold in the summer, partly in the town of Pavlovsk, yet Kurosawa chooses winter Hokkaido to set the scene for his adaptation.

The disproportion between the huge snow banks and small human figures seems to reinforce the tense and ominous vibe of irrationality. Kaneda's getting lost in a snowstorm precedes the scene of his first epileptic seizure: the city appears as if in a deformed shape and eventually becomes a trap for him. The snow acquires double symbolic-metaphorical interpretation: on the one hand, it represents the symbol of purity and innocence, white being the color of a wedding dress which neither of the heroines is destined to wear, on the other hand, it symbolizes death, as white is the color of mourning in Japanese and Chinese cultures. It is always present in all key scenes of the film, including indoor ones.

The scene of Taeko's birthday is remarkable. Every detail here has very serious content and purport. Numerous plants in her house convey the impression of a warm and cozy greenhouse, but the snow on its glass ceiling points to a cold forthcoming storm. Transparency of the room also emphasizes vulnerability of the heroine and the lack of confidentiality, as her private life is put on display for the entire world to see.

"Dostoevsky by nature had a keen sense of life and death which was grounded in the very depths of his essence" [7, p.9]. This was largely due to his life experience and epilepsy, during the seizures his body and soul were in between these two conditions. 
From the diary of the writer's wife, we learn that while working on his novel the writer was struck by seizures especially frequently. "In these moments his face was scary to such an extent that, that I was just terrified of him ... He kept saying that he was afraid to die so terribly and I should look after him" [8, p.189-190]. The novel is permeated with a sense of fear of death and a desire to comprehend its meaning. Akira Kurosawa managed to embody this motif into visual imaging. It looks like we see death running around in the air, hiding in the constant and ubiquitous snow.

First encounter of Kameda with Taeko Nasu (Nastasya Filippovna), more precisely, with her portrait in a photo shop window, also occurs in the presence of the shadow of death. The glass reflects Akama and Kameda with beautiful Taeko between them as if her portrait were the central image on an Orthodox triptych with the upcoming figures symmetrically located on both sides of it (Fig. 1). Taeko, like the Virgin, illuminated by spiritual light, evokes a feeling of solemn sorrow. At the same time the picture where she is portrayed in a white background reminds of a photo of a deceased person. Kameda who sympathizes with Taeko's misfortune and is moved almost to tears mourns her in advance. Thus, the director predicts the fate of the heroine and illustrates vividly the contrasting attitudes of the main characters to her, as their love is so different.

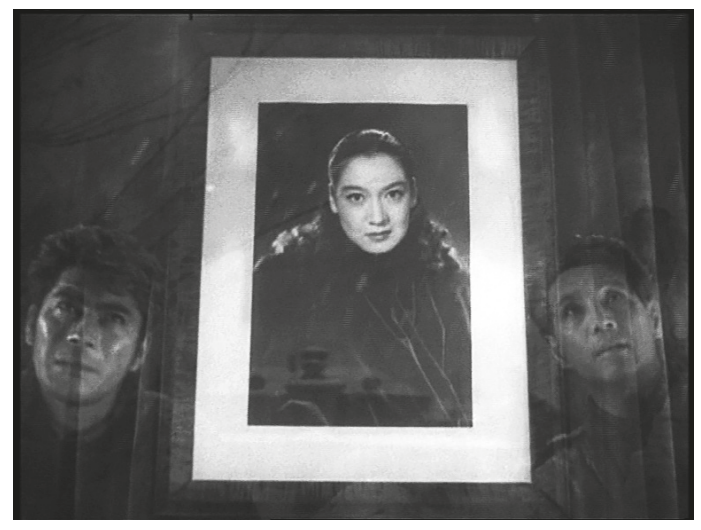

Fig. 1. Movie still from Akira Kurosawa’s “Idiot”, 1951

In his childhood, Kurosawa had studied painting, later it came in handy for him in directing. Kurosawa drew detailed storyboards for his films, which were then carefully and accurately embodied in cinematic imagery.

In the scene at the photo shop window the geometricity of Kurosawa's frame is revealed - the exact spatial arrangement of two or multi-figured compositions - which is what will happen many times over the course of the film.

The narrative moves along with the main storyline of Dostoevsky: Kameda gets acquainted with the Ono family (the Epanchins), tells Ayako (Aglaya Epanchina) in detail about his failed execution and about a promise he made that he would become kinder to everyone if released.

It is no accident that the Ono family keeps a farm, part of the revenue from which belongs to Kameda. In the scene of Kameda's walk with Ayako over the snowy field, the girl asks him a significant question: "If it were your pasture, would you be happy? If the cows were yours?" It is a widely known fact that Dostoevsky imparted to the image of 
Prince Myshkin some features of Christ as the Good Shepherd. Besides, the surname of Nastasya Filippovna - Barashkova - originates from a Russian noun which meaning "lamb", in the Gospel the image of the lamb symbolizes sacrifice and resurrection. In the same manner as with Taeko's icon portrait Kurosawa further elaborates Dostoevsky's theological motif.

A consequence of Shochiku studio's involvement in this film, making the editing done without the director's consent, was the presence of certain plot inconsistency, and yet we cannot fail to recognize Kurosawa's deep understanding of Dostoyevsky's narrative which is at the core of his knowledge of Western Christian ideology, and, most importantly, Kurosawa's talent to expound and present his reading in a completely different cultural milieu.

Of significance is the episode where Kameda slapped Kayama (Ganya Ivolgin) in the face. Analysis of this scene reveals the importance of the details of the interior in Kayama's house. Sliding doors are decorated with hieroglyphic inscriptions - quotations from poetry books and studies on the history of ancient China. One of the quotes comes from a biography of emperor Di Ku which is described in the Chinese text entitled "The Records of the Scribes" (Shǐji 史記) compiled by Sīmă Qiān in 104 BC.

Kurosawa implements his interpretation of Dostoevsky's novel through the prism of the national tradition of his country and its Chinese origins, where the values of goodness and compassion play a crucial role.

In this scene, a non-Japanese audience, perhaps, for the first time during the film, gets an idea to compare Kurosawa's style with the techniques of Japanese classical theater. When slapped, Kameda puts his hand on his cheek with a gesture that closely resembles kata (ritualized, symbolic movements) practiced by Noh actors.

Generally speaking, the striking feature of all the characters' gestures is that they are restrained, sharpened, skillfully crafted, especially with Kameda. At times, especially when he is worried - which happens all too often considering his fragile health - Kameda holds his cupped palms to his throat (Fig.2). In another scene Kameda uses a gesture of sorrow typical to Noh play.

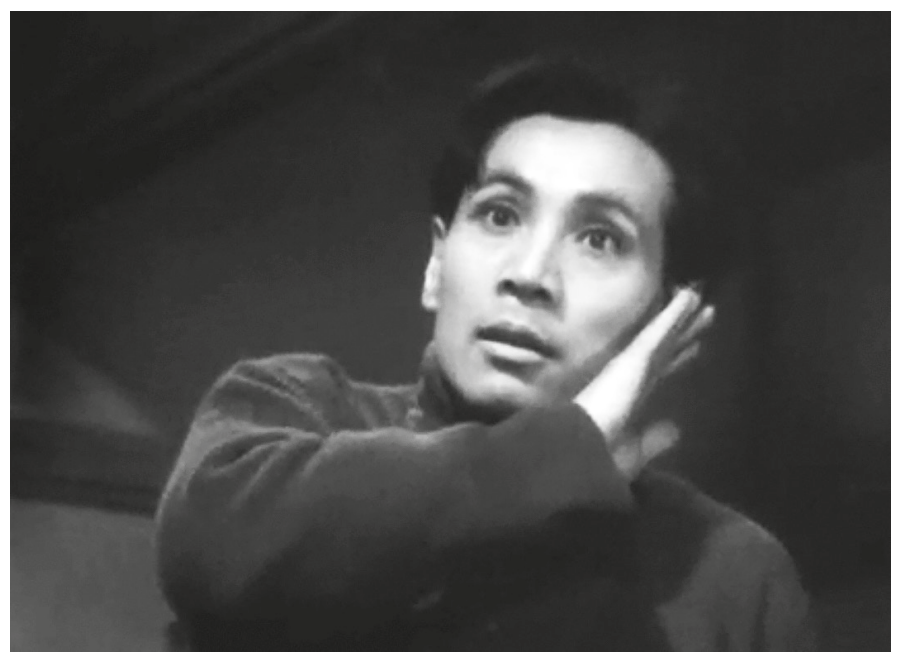

Fig. 2. Movie still from Akira Kurosawa's “Idiot”, 1951 
And the recognizable melody by Edward Grieg "In the Hall of the Mountain King" then starts playing.

Restraint and perfection of all movements, which highlight immense inwardly directed energy, are the features which distinguish Noh theater and it is those traits that become an important focus in Kurosawa's narrative. Once noticing this, one cannot avoid having further associations discovering that the main actors of the drama are nothing but masks.

Personality of a Noh actor vanishes completely being swallowed by the character of the mask and that is how the actor finds his own true nature. In case of Kurosawa's film the audience following the actors' play, which is conceived of as embodying the mask, is able to embrace the very depth of feeling and experience. Kurosawa, along with Dostoevsky's concept, emphasizes suffering as the most significant reality displayed in "The Idiot". Catharsis, comprehension of the deep human essence, become possible through complete integration and dissolution.

The narrative moves further; the experience of execution by a firing squad, which Kameda went through is fundamental for him and leads the character through a tangle of human passions with their struggle of pride versus greed, humiliation versus power, and a desperate desire for happiness shot through a tapestry of endless human suffering. Kameda meets Taeko's gaze, and he has a sudden memory flash of a twenty-year-old man who was shot dead in his plain sight. That look on the condemned prisoner's face seemed as if it were asking a question: "Why do I deserve this pain?" This abstract image of the condemned prisoner from Dostoevsky's novel is interpreted by Kurosawa as a war martyr - a significant association for the Japanese as well as for other nations struggling to emerge from a war trauma.

Seeing this image of Taeko, Kameda sees her real self, suffering and fragile. He tells her about it. And again the scene is geometrically exact. Two people, located in the frame symmetrically relative to its center, the actors are cast facing each other with their profiles oriented towards the viewer. In the middle of the crowd, these two understand each other, really see each other.

Another important psychological pattern which Kurosawa considered important to emphasize is the human ability to look and hold their gaze, without taking their eyes off the object; in particular, this is what constitutes geometry of Kurosawa's shooting frames.

Noh actors may stand a few steps apart, but they do not feel each other's presence until they have faced each other. Kurosawa's film presents a dialogue of souls which is always indicated by faces mutually turned towards each other, scenes are arranged in a special manner: side characters are usually located at right angles to main ones. Such geometric clarity of all important mise-en-scenes is characteristic of the narrative as a whole. If other characters are present in the scene except those who participate in the dialogue, they often form a certain frame shaped into a regular polygon with the main characters at its center, such as in the Figure 3. Items of the interior perform the same function. For example, they can divide a frame into regular halves or demarcate the space in which a significant character is located.

Geometry of stage being something Kurosawa manages perfectly, he is equally adroit at creating an "atmosphere" of a scene. Interiors featured in the film are typical of Japan of that time. European style prevails, however, and some elements of traditional lifestyles, as in the room of Akama's mother are engaged as well. Ubiquitously applied geometry in 


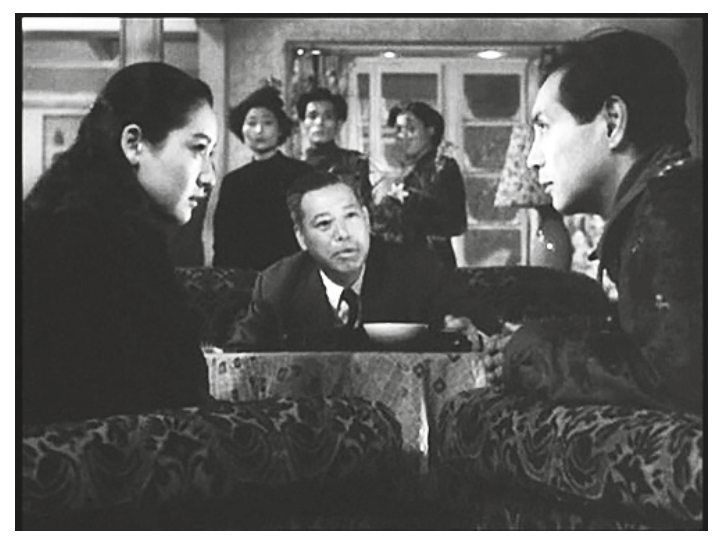

Fig. 3. Movie still from Akira Kurosawa's “Idiot”, 1951

the play of light and shadow combined with geometry of arranging human figures leaves a strong impression of particular uncanny gloominess.

Most of the scenes take place in shadows, twilight, in semi-dark rooms. In that regard Kurosawa completely follows the original. Andre Gide asserts: "In Dostoevsky's books, as in a Rembrandt portrait, the shadows are essential" [quot. from 9, p.47]. This artistic technique appeals to Japanese culture, as Junichiro Tanizaki, one of the major authors of modern Japanese literature, most vividly displays in his aesthetic essay "In Praise of Shadows" where he attests that the shadow is the very essence of Japanese aesthetics.

"The Idiot" is perhaps the darkest (in the literal sense) Kurosawa's film. This applies not only to high concentration of mental suffering, but also to presence of light in the frame. Most of the episodes are filmed in a shaded studio, and the street ones - in the dark, where even snow banks seem black. Narrow and dark hallways and staircases in Akama's house, streaks of moisture on the walls, snow banks lying right in cross passages leading to other parts of the house... The long and terrifying scene of Kameda's seizure is constructed with the use of flitting shadows and shifting space. In the night scene on the ice rink, demonic masks with burning torches appear to the sounds of Mussorgsky's "A Night on Bald Mountain" only to increase the tension that is being escalated little by little as events unfold.

Kurosawa's key characters form the following oppositions: Taeko - Akama, Taeko Kameda, Kameda - Akama, Kameda - Ayako, Taeko - Ayako.

Main scenes with the pairs of contrasted characters may be conceived of as two-figure symmetrical compositions in which a vibration of the powerful energy of the opposites occurs. If Dostoevsky's "The Idiot" is intended to portray a "good and beautiful person", Kurosawa's film is also construed as embracing vibrating interactions of the opposites' mutual attraction-repulsion which is where the director sharpens specific artistic techniques, such as the geometry of relationships, where the elusive movements of human souls take a visible form of two- or multi-figure arrangements shaped according to the principles of pictorial composition. Equilibrium, diagonal or shifted lines of figures in the frame pulse with internal energy of passion.

Japan is a country whose heart beats in its landscapes, the sounds and forms of this ancient civilization. The canon of Noh theater, which dates back to the $14^{\text {th }}$ century, is 
one of those forms. The principles of Noh play are evident in the scene of Ayako and Taeko's meeting in Akama's house. Ayako and Kameda are very slow at the moment they enter the house. Their movements are so slow that, passing by the transparent stainedglass window with circles and squares, they seem to float in synchronism with the time itself which is relentlessly counting seconds before the tragic denouement. Movements are smooth, postures are static. Taeko wears a black dress almost entirely covering her figure, resembling a cape of death, her elongated silhouette is almost motionless. The faces - frozen, and at the same time, paradoxically, surprisingly alive - narrate a silent dialogue of two women by smallest changes of facial expressions, by eyes and movements of eyebrows. The motions of the figures are symbolic, as are the angles of faces' rotation and camera angles.

All actors are located in two mutually perpendicular planes: the women facing each other, the men at an angle of ninety degrees to them looking forward, peering into the void. Long pauses, fueling tension, a fire suddenly flashing in the stove - a symbol of passion. Faces appearing in close-ups cause an association with living Noh masks which clearly manifest what characters deeply feel. Slow movements and frozen postures echo the manner Noh actors play engaging "especially expressive rhythms of performing arts, when the actors, freeze motionless for a moment in certain poses to show that the action or feeling has reached the culmination" [10, p. 135].

The Japanese and the European concepts and understandings of the mask have fundamental distinctions. Japanese culture empowers the mask not to conceal but to disclose and express the character played by the actor and to concentrate aesthetic culmination of human passions in a symbolic form. "The Idiot" is, perhaps, the most meditative film ever made by Akira Kurosawa.

While watching the film, at times, the viewer is affected by a cognitive dissonance: on the one hand, it is obvious that the events take place in Japan, with Japanese behavioral patterns represented throughout, on the other hand, one cannot turn a blind eye to the fact that this is Dostoevsky, as both narratives - of Kurosawa and Dostoevsky - are similar in form and content. Thus, Kurosawa's characters are perceived as referring simultaneously to different cultural traditions. Akama's mother sitting in the traditional pose of Japanese women - on her knees - at the altar, arranging an offering of cake, followed by making traditional Japanese tea - the woman at some point morphs into a perfect image of Rogozhin's mother as portrayed by Dostoevsky, although she fully remains Akama's mother too. Thus, Dostoevsky's aesthetics and concepts as well as the ancient Japanese tradition are closely intertwined in Kurasawa's style. Being able to creatively penetrate deeply into the world of the Russian culture Akira Kurosawa still remains an invariable carrier of oriental tradition and world outlook, in particular, as regards religious concepts representing ideas of death. The scene at Rogozhin's house is infused by Dostoevsky with the atmosphere of grim mystery and impending tragedy of murder. This special atmosphere of mystery, anxiety and unbearable burden does not come so much from the havoc in the heroes' hearts or from the awareness of their tragic fate, but from the inevitability of the redeeming sacrifice they have to make. By giving this episode a Buddhist tranquility, Kurosawa softens despair. In this scene, Kameda and Akama exchange amulets instead of crosses as in Dostoevsky's "The Idiot". The amulet of the former is a stone which Kameda was clutching during seizure that struck him right before his execution was called off. The cross of Dostoevsky's Prince Myshkin has a different origin, bought from a soldier who 
wanted to sell his tin cross as a silver one so he could get money for a drink. This ugly episode is intended by the writer to illustrate the issue of moral decay he sees as critical in his time when people do not know what such notions as "piety" and "God fearing" mean: «the Russian soul is a dark place» indeed. As to Akira Kurosawa, he focuses to a larger extent on the life journey and emotional experience of his protagonist who serves as a metaphor of the Japanese people and the entire country of Japan.

In his "The Idiot" the Russian writer is straightforward in revealing a cold death, while the Japanese director rather creates an "atmosphere of death" in his adaptation avoiding a direct display. It is difficult to remain indifferent and not to give in to the oppressiveness expressed by the episode where Dostoevsky brings attention to the Hans Holbein the Younger's picture "The Death of Jesus Christ". The deceased Jesus is depicted in this painting so naturalistically that

"[a]s one looks one looks at the dead body of this tortured man, one cannot help asking oneself the peculiar and interesting question: if such a corpse (and it must have been just like that) was seen by all His disciples ... by all who believed in Him and worshipped Him, then how could they possibly have believed, as they looked at the corpse, that that martyr would rise again? The question instinctively arises: if death is so awful and the laws of nature so mighty, how can they be overcome? How can they be overcome when even He did not conquer them... This picture expresses and unconsciously suggests to one the conception of such a dark, insolent, unreasoning and eternal Power to which everyone is in subjection" [11].

Such a frank, vivid and detailed description of death which the Son of God bore and the direct expression of doubt in His immortality seem impossible to Buddhist culture, where death of every being is followed by rebirth. The film shows a conversation between the main characters about faith, but not about death. The dead body of Nastasya Filippovna is hidden from the viewer's eyes for the same reason.

In the very end, Kameda's candle casts a moving openwork shadow on the partition behind which Taeko is "sleeping" as if dividing her from the world of the living, creating through this play of light and shadow a thin, but unbreakable veil between our world and the other world.

The language of literature, the verbal narrative of the novel is transformed by Kurosawa into the language of form and plastics - the "language of the visual". And this is not just a translation of the work in the process of its transition from one genre to another, but a radical transformation of the substance of the narrative through audio-visual medium into a geometry of space. The shape of the frame is comprehended as an expression of feelings and ideas. Kurosawa in his interview with Bert Cardullo noticed that "it is very difficult to convey literary images to the audience through cinematic images" [12, p. 146].

A strong connection between Dostoevsky and Kurosawa which brings their works closer together is due to their ability to study, in a profound and subtle way, the being of the spirit. The humanistic views of Kurosawa permeate the film, overwhelming him with love for the humiliated and the suffering. The polyphony of the novel seems to narrow down to the quadrangle of the key characters who co-exist and interact, love and suffer. The main media here engaged by Kurosawa are not only dialogues as in Dostoevsky, but an arrangement of space in the cinematographic frame. 
The director makes the complex and ramified plot of the novel cinematic, sacrificing everything which is secondary to the main idea. The picture is a series of scenes, rather static at first glance, but still full of internal energy, between the scenes there seems to be a gap of the all-absorbing Buddhist emptiness, containing in itself all the necessary alchemy for connecting the plot into a single whole. Development of characters does not happen, only their inner essence unfolds and manifests itself in accordance with its deep logic.

The director's work on the film was the most intense, the experience was completely different from everything he had done before. Kurosawa said about the film: "If I was asked which of my films I prefer, I would say "The Idiot". Criticism, however, appeared to be not very encouraging. Kurosawa was accused of excessive theatricality, incoherence of the plot, and reducing the idea of the film to a love drama. Thus, in his study of the Akira Kurosawa's cinema Prince concludes:

"The spiritual and aesthetic compatibility he felt with Dostoevsky, however, may actually have been a problem, for his version of "The Idiot" is as close to an embarrassingly poor film as he has ever come. The performances are mannered and overwrought, yet the camerawork is so restricted and conventional that much of the film comes to have the air of filmed theater. It is difficult to watch, a remarkable defect for as gifted a story teller as Kurosawa. The work is largely incoherent, though this is probably not Kurosawa's fault." [4, p. 139].

However, the features perceived by some critics as shortcomings may prove to be merits of the film, given the Japanese theatrical tradition, clearly seen in Kurasawa's "The Idiot". In this regard, the comparison of Kurosawa's "The Idiot" with "Nastasja" - directed by the renowned Polish cinematographist Andrzej Wajda (1994) seems to be of particular significance. Both film makers seem to comprehend the similarity of fundamental principles between Dostoevskian and Japanese aesthetics. The major distinction lies in the artistic approach to Noh theater. As shown above, Kurosawa treats the elements of the Japanese Noh play as an artistic technique for revealing the characters' key lines and Wajda's film is completely constructed from the aesthetic experience of this ancient Japanese art.

Andrzej Wajda, a younger contemporary of Kurosawa, during his work on the adaptation of Dostoevsky's novel departs from the screen version of the Japanese director, often debating with him. While Kurosawa presents a slow, meditative Noh, Wajda introduces a seemingly more democratic Kabuki in combination with the compositional and ideological patterns of the Noh theater. The influence of the Japanese director's cinema on the work of the Polish master enables Wajda to rethink the intersection between Dostoevsky's world vision and the Japanese cultural code and, based of his own cultural tradition, interpret the relationship between East and West. Compared to Kurosawa, Wajda goes to some extent further as he attempts to develop both the Russian aesthetics of Dostoevsky's novel and the Japanese aesthetics which imbue Kurosawa's film from the third angle - not Japanese or Russian, but a Polish one.

Wajda in his interview notes that even now Dostoevsky's creative writing enjoys great popularity in Japan:

"You need to know that in Japan doing a theatre or a film adaptation of Dostoevsky's works is a great joy, because Japan is obsessed with Dostoevsky. The number of critical and literary studies on Dostoevsky published in the country every year in the past used 
to be much bigger than that released in the Soviet Union and, probably, than that being now published now in Russia. Dostoevsky is so deeply rooted in the consciousness of the Japanese intelligentsia that there was no question of why we chose Dostoevsky and not someone else to adapt to the screen" [13].

The cast of Wajda's "Nastasja" are all Japanese, as are part of the crew. The film is in Japanese. Aesthetics of the film is constructed from artistic techniques typical for the Kabuki drama, in particular, male-onnagata tradition, where female parts are played by men. Wajda's innovation here is that in his film the onnagata actor is cast simultaneously in two parts.

The film "Nastasja" and this particular feature of it had a prehistory. In 1989, Wajda staged in Tokyo the play entitled "Nastasya Filippovna" based on the Dostoevsky's "The Idiot" with the famous onnagata actor, i.e. a performer of female parts in the Kabuki, Tamasaburo Bando starring both Nastasya Filippovna and Prince Myshkin. Five years later, Wajda transferred the play to the screen.

The director makes the following comment on his innovative approach implying that onnagata should play two main characters of different genders:

"Since everything is possible for Dostoevsky, I decided that both Myshkin and Nastasya would be played by one person. Meeting with this great actor encouraged me to perform a wonderful creative experiment" [14].

The experimental reading of Dostoevsky's novel was to a large extent due to the fact that in a film format Wajda staged a play of Japanese traditional mixed-style theater marked by both Kabuki and Noh aesthetics and artistic techniques. At the same time Nastasya Filippovna and Prince Myshkin are comprehended as alter egos for each other. In this context, the dual part the onnagata played, partially blurred gender boundaries.

Onnagata tradition has been an essential part of Kabuki drama since its very inception in the $17^{\text {th }}$ century. Onnagata acting skills include a specific language of gestures and poses as well as a special make-up. As Mezur indicated,

"[t]hroughout the 300-year history of professional kabuki theatre, men have performed both female and male gender roles... With the official government edict in 1629 that prohibited women from performing in public, men, particularly youths, took over the theatrical representations of kabuki's female gender roles. In these early stages of exclusively male kabuki, performers generally specialized in either female gender roles or male gender roles. The female gender role specialists were called onnagata,.. Over time, onnagata creatively formulated fantastic female-like gender roles constituted from stylized gender acts. Gradually, an ideal fiction of "female-likeness,"... Thus, the onnagata did not aim at "representing" women; they performed their own many layered "vision" of a constructed female-likeness." [15, p. 1-2].

Unlike the Noh theater the Kabuki does not make use of masks.

It is significant to note that in Wajda's "Nastasja" Tamasaburo Bando had to predominantly play the male part of Prince Myshkin. The heroine, whose name the film is titled after, appears only in a few episodes. But both of them represent, as it were, a single whole, two sides of the same person. A good and beautiful man and seemingly vicious woman endowed with internal purity of soul are connected through the play of one actor. Is that why Prince Myshkin knows Nastasya Filippovna and understands her so well that 
they are one? At the very moment of her murder, Myshkin feels that pain she bears when the knife goes into her heart.

Bando transforms from Prince Myshkin into Nastasya Filippovna right in the course of action, taking off his thin gold-rimmed glasses and draping a white shawl over his shoulders. This symbolic transformation expressed in changing ones clothes right on the stage, in front of the audience is a typical feature of the Kabuki theater. The boundaries of space and time are easily crossed without any jump cuts.

Another peculiarity of Kabuki which Wajda introduces in the very first frames of the film: the first viewer's encounter with Wajda's heroine happens when she appears in the passage between people standing in the street at the entrance to the church, thus entering the narrative. In the Kabuki drama, there is a notion of hanamiti, which means "the flower way", "a passage leading to the stage through the left section of the theatre... The use of the hanamiti is considered very important and productive of histrionic effect" [16]. In Wajda's film the crowd serves as hanamiti for Nastasya Filippovna.

Throughout the whole film heroes do not leave the huge room with columns and a high ceiling - rather the hall than the study in the house of Rogozhin, where the murdered Nastasya Filippovna lies behind the curtain. The tragic denouement has already set on, the narrative moves forward in a spiral either from the denouement or back to it, reinforcing the feeling of inevitable death. Prince Myshkin and Rogozhin experience all the plot twists which led to the tragic finale without leaving the room, being around next to the dead Nastasya Filippovna. The past is shown through the present - another trait featured in the Noh theater.

"The two time scopes of the Noh drama - the present and the past - are clearly distinguishable and at the same time bound together, connected by a string of the constant human memory. Locations inspire the sense of an organic relationship between the past and the present as they simultaneously exist across both the present and the past. Time, like locations, appears as a meaningful artistic image expressing the idea of frailty of existence" [17].

The analysis of Wajda's reading of Japanese aesthetic and philosophical patterns widely known through traditional Japanese theater reveals the fact that his film bears all the outward hallmarks of the Kabuki, such as the scene which introduces Nastasya Filippovna by the use of metaphorical hanamiti, the involvement of onnagata, the symbolic transformation expressed in changing ones clothes right on the stage, in front of the audience. However a deeper examination of the narrative shows that film composition and the most important concepts of narration refer rather to the Noh drama.

Wajda's film may be conceived of as a play with time and space, although the events unfold in one interior as a vigil by the bedside of deceased Nastasya Filippovna. Without leaving Rogozhin's study the characters change their locations in the room and experience different situations. The scenes presented in the film refer to different time frames. Time moves forward with loops, then turns of a spiral, and all situations, enclosed one into another by the external unity of place and time, inexorably lead not forward, but towards the center - to death, which has already occured. Time and space are conditional and unsteady, shifted and combined.

Through his film Wajda introduces the audience to the notion of the contemplation of the world which is fundamental for the Noh drama. He discusses Buddhist principles of 
karma - the concept of cause and effect and the illusory nature of the common sense world. Although, at a superficial glance, one can get an impression that the intermixture of the time scopes seems to violate the consistency of causes and effects, the inner logic of the narrative, the movement of time in a spiral only confirm the inevitable course of events.

So, in the Noh drama "... every moment for the character is an experience and awareness of the past, karmic connections, which determine his or her present state. Returning to the past is the key to understanding the hidden secrets of the soul. The past for the hero continues to live in the present..." [17]. The director himself considered his film very close to the staging. "I made a film from those records that I had left (from the play "Nastasya Filippovna" staged in Tokyo). It certainly is not cinema but something in between" [18].

Compared to Kurosawa, Wajda reduces plot lines and the number of characters to an even greater degree. Actually in Wajda's film there are only three of them left: Parphyon Rogozhin, Prince Myshkin, Nastasya Filippovna who in reality just enters through the character of Myshkin a few times. In fact, all collisions occur between Rogozhin and the Prince. Nastasya Filippovna is a catalyst, a symbol; not by chance, she is most conditional, ghostly element of the film, particularly, in one of the scenes, where she is represented by a white dress only. Bando plays Nastasya Filippovna masterfully employing the whole set of specific Kabuki techniques, while Myshkin and Rogozhin are played in a more realistic manner.

Parfyon Rogozhin treats the Prince with mixed feelings, such as love and hate, jealousy and tenderness at the same time. They are connected to such an extent as only complete opposites can be, so firmly that could be compared with lovers, especially since Wajda purposely mixes the gender of the Prince and Nastasya Filippovna, and she appears from the depths of Myshkin.

In Wajda's interpretation Rogozhin is a simpler, more down-to-earth person than in Kurosawa's reading. If to compare him with Kurosawa's Rogozhin we should state that his loss of the spiritual foundations of his essence to the animalistic ones is revealed in a more clear and obvious way. He is rather anxious to hide the traces of the crime than grieves for the murdered woman.

Wajda's development of the two-dimensional personality of Myshkin/Nastasya Filippovna also seems less profound than that of the Japanese director. The subtle play of Bando does not go beyond the limits of the Wajda's task who reduced the extent of the plot of the Dostoevsky's novel and the multifacetedness of its meanings. The denouement proposed by Wajda, as in Dostoevsky's novel, does not reflect anything approaching the catharsis that Kurosawa showed.

In comparative analysis of the two films - Kurosawa's "The Idiot" and Wajda's "Nastasja" - we reach the conclusion that the work of the Polish director is inferior to Kurosawa's picture in terms of creativity and relevance, despite being very innovative. The use of Japanese drama techniques introduced in the film has no reference to Dostoevsky's ideas or director's general reflections on his time. Andrzej Wajda's desire for experimenting with shape and form prevails over the task of reading Dostoevsky's ideas, while Akira Kurosawa aims precisely at conveying the essence of the Russian novel and that is where he succeeded most convincingly. 


\section{References}

1. Kinosita T. Antropologiia i poetica tvorchestva Dostoevskogo: sbornik statei [Anthropology and the Poetics of Dostoyevsky. Collection of articles]. St. Petersburg, Serebrenii vek Publ., 2005. 208 p. (In Russian)

2. Richie, Donald. The Films of Akira Kurosawa. Berkeley, Los Angeles, University of California Press, 1998. $273 \mathrm{p}$.

3. Kurosawa, Akira. Something Like An Autobiography. Translated by Audie E. Bock. New York, Knopf Doubleday Publishing Group. 240 p.

4. Prince, Stephen. The Warrior's Camera: The Cinema of Akira Kurosawa. Princeton, New Jersey, Princeton University Press, 1999. 417 p.

5. Satō, Tadao. Currents in Japanese Cinema. Translated by Gregory Barrett. New York, Kodansha International, 1987. $288 \mathrm{p}$.

6. Ghens I. Tosiro Mifune [Toshiro Mifune. Masters of Foreigh Cinema]. Moscow, Iskusstvo Publ., 1974. 134 p. (In Russian)

7. Nakamura K. Chuvstvo zhizni i smerti Dostoevskogo [Dostoevsky' Sense of Life and Death]. St. Petersburg, Dmitry Bulanin, 1997. 331 p. (In Russian)

8. Dostoyevskaya A. G. Rasshifrovannii dnevnik [Deciphered Diary. Literary Heritage in 105 volumes]. Moscow, Nauka Publ., 1973, vol. 86, pp. 155-290. (In Russian)

9. Patterson, David. Literature And Spirit: Essays on Bakhtin and His Contemporaries. Lexington, Kentucky, University Press of Kentucky, 2015. 176 p.

10. Gundzii M. Iaponsky teart Kabuki [Japanese theatre Kabuki]. Moscow, Progress Publ., 1969. 221 p. (In Russian)

11. Dostoevsky, F. Complete Novels of Fyodor Dostoyevsky: Novels and Novellas by the Great Russian Novelist, Journalist and Philosopher, including Crime and Punishment, The Idiot, The Brothers Karamazov, Demons, The House of the Dead and many more. Translated by Constance Garnett. E-artnow, 2015. 3800 p.

12. Cardullo, B. (ed.). Akira Kurosawa: Interviews. Jackson, Univ. Press of Mississippi, 2008. 194 p.

13. Rubanova I. I. Andrzei Waida: Ekhat' v Ameriku mne bylo nezachem [I Didn't Need to Go to America]. Izvestia. 06.05.2013. Available at: http://izvestia.ru/news/276311 (accessed: 06.05.2016). (In Russian)

14. Lubarskaya I. Yu. Peisazh posle bitvy [Landscape after the Battle]. Itogi. 06\608 04.02.2008. Available at: http://www.itogi.ru/iskus/2008/6/3374.html (accessed: 04.05.2016). (In Russian)

15. Mezur, K. Beautiful Boys/Outlaw Bodies: Devising Kabuki Female-Likeness. New York, Palgrave Macmillan, 2005. 319 p.

16. Miyake, Syutaro. Kabuki Drama. Routledge, 2013. 74 p.

17. Anarina N. G. Iaponsky teatr No [Japanese theatre Noh]. Available at: http://lib.vkarp.com/2013/09/04/ анарина-н-г-японский-театр-но/ (accessed: 04.05.2016). (In Russian)

Received: 06.05.2016

Accepted: 27.02 .2018

Author's information:

Xiaoxing Wang — postgraduate student; anotherherainspb@hotmail.com

\section{Сравнительный анализ киноинтерпретаций романа Ф. М. Достоевского «Идиот» Акиры Куросавы и Анджея Вайды}

C. Вaн

Московский государственный университет им. М. В. Ломоносова, Российская Федерация, 119234, Москва, Ленинские горы, 1

Для цитирования: Wang X. Interpretations of Fyodor Dostoevsky’s “The Idiot” by Akira Kurosawa and Andrzej Wajda: A comparative analysis // Вестник Санкт-Петербургского университета. Востоковедение и африканистика. 2018. Т. 10. Вып. 2. С. 159-175. https://doi.org/10.21638/11701/ spbu13.2018.202 
К наследию Ф.М. Достоевского неоднократно обращались и продолжают обращаться кинорежиссеры со всего мира, в том числе и из далекой Азии. Яркой попыткой «перекодировки» текста Федора Михайловича Достоевского в азиатской кинематографии является «Идиот» японского режиссера Акиры Куросавы. Прежде всего этот фильм делают особенным вольные изменения Куросавы в месте и времени действия. История развивается в середине XX в. на заснеженном острове Хоккайдо, в послевоенной Японии с японскими героями. Помещая историю в японские реалии, Куросава не иллюстрирует литературное произведение, а переплавляет первоисточник в кинематографическую форму, передавая в точности дух романа Достоевского. Но в то же время, несмотря на глубокое понимание русского мира, великий режиссер остается неизменным носителем восточного культурного кода. Истолкование произведения Достоевского Акира Куросава ведет сквозь призму истории и национальной традиции своей страны. Печать древней азиатской культуры в фильме проявляется как в сюжетной линии, так и в визуальном ряде. Как и в других картинах Куросавы, в «Идиоте» применены приемы древнего японского театра Но. Для сравнения в статье приведен анализ фильма польского режиссера Анджея Вайды «Настасья», снятого по мотивам романа Достоевского и построенного также по эстетике традиционного театра Японии.

Ключевые слова: Ф. М. Достоевский, Идиот, Акира Куросава, Настасья, Анджей Вайда, 1951 г., театр Но, театр Кабуки.

Контактная информация:

Ван Сяосин - аспирант; anotherherainspb@hotmail.com 